\title{
Adherence to cancer prevention recommendations and antioxidant and inflammatory status in premenopausal women
}

\author{
Yukiko Morimoto $^{1}$, Fanchon Beckford ${ }^{1}$, Robert V. Cooney $^{2}$, Adrian A. Franke ${ }^{1}$ \\ and Gertraud Maskarinec ${ }^{1 *}$ \\ ${ }^{1}$ University of Hawaii Cancer Center, Epidemiology Program, 701 Ilalo Street, Honolulu, HI 96813, USA \\ ${ }^{2}$ Department of Public Health Sciences, University of Hawaii, Honolulu, HI, USA
}

(Submitted 6 October 2014 - Final revision received 16 March 2015 - Accepted 17 April 2015 - First published online 8 June 2015)

\begin{abstract}
For cancer prevention, the World Cancer Research Fund and American Institute for Cancer Research (WCRF/AICR) emphasise recommendations to improve individual behaviour, including avoidance of tobacco products, maintaining a lean body mass, participating in physical activity, consuming a plant-based diet, and minimising the consumption of energy-dense foods, such as sodas, red and processed meats and alcohol. In the present study of 275 healthy premenopausal women, we explored the association of adherence scores with levels of three biomarkers of antioxidant and inflammation status: serum C-reactive protein (CRP), serum $\gamma$-tocopherol and urinary F2-isoprostane. The statistical analysis applied linear regression across categories of adherence to WCRF/AICR recommendations. Overall, seventy-two women were classified as low ( $\leq 4), 150$ as moderate (5-6), and fifty-three as high adherers ( $\geq 7$ ). The unadjusted means for CRP were $2 \cdot 7,2 \cdot 0$ and $1.7 \mathrm{mg} / 1$ for low, moderate and high adherers $\left(P_{\text {trend }}=0.03\right)$; this association was strengthened after adjustment for confounders $\left(P_{\text {trend }}=0.006\right)$. The respective values for serum $\gamma$-tocopherol were $1.97,1.63$ and $1.45 \mu \mathrm{g} / \mathrm{ml}\left(P_{\text {trend }}=0.02 \mathrm{before}\right.$ and $P_{\text {trend }}=0.03$ after adjustment). Only for urinary F2-isoprostane, the lower values in high adherers $(16.0,14.5$, and $13.3 \mathrm{ng} / \mathrm{ml}) \mathrm{did} \mathrm{not}$ reach statistical significance $\left(P_{\text {trend }}=0 \cdot 18\right)$. In an analysis by BMI, overweight and obese women had higher biomarker levels than normal weight women; the trend was significant for CRP $\left(P_{\text {trend }}<0.001\right)$ and $\gamma$-tocopherol $\left(P_{\text {trend }}=0.003\right)$ but not for F2-isoprostane $\left(P_{\text {trend }}=0 \cdot 14\right)$. These findings suggest that both adherence to the WCRF/AICR guidelines and normal BMI status are associated with lower levels of biomarkers that indicate oxidative stress and inflammation.
\end{abstract}

Key words: Chronic inflammation: Cancer prevention: Nutrition: Lifestyle: Recommendations

Nutritional and lifestyle factors are thought to be associated with a higher risk for cancer and other chronic conditions, but little is known whether guidelines from different agencies are related to indicators of lower disease risk. The World Cancer Research Fund and American Institute for Cancer Research (WCRF/AICR) emphasise recommendations to improve individual behaviour, including avoidance of tobacco products, maintaining a lean body mass, participating in moderate physical activity, consuming a primarily plant-based diet and minimising the consumption of energy-dense foods and drinks, red and processed meats and alcohol ${ }^{(1)}$. In two large cohort studies, participants experienced a 9 to $10 \%$ lower mortality for each WCRF/AICR recommendation that was met ${ }^{(2,3)}$. Based on evidence that chronic inflammation plays a major role in cancer development ${ }^{(4,5)}$, we evaluated the diet of 275 healthy premenopausal women who completed a FFQ and explored the association of adherence scores with levels of three biomarkers of antioxidant and inflammation status: serum C-reactive protein (CRP), urinary F2-isoprostane and serum $\gamma$-tocopherol. CRP represents a non-specific indicator of inflammation ${ }^{(6)}$ that has been associated with cancer incidence ${ }^{(7)}$ and survival ${ }^{(8)}$. Among markers of oxidative stress, F2-isoprostanes are considered the 'gold standard' because they are stable and specific and are only formed directly by chemical oxidation from $\mathrm{NO}_{x}$ generated in vivo ${ }^{(9-11)}$. Owing to their antioxidant activity, tocopherol isomers may shield against oxidative damage ${ }^{(12,13)}$. In particular, $\gamma$-tocopherol selectively protects cells from the DNA-damaging effects of $\mathrm{NO}_{x}^{(14-16)}$, possesses anti-inflammatory activity ${ }^{(17)}$, and rises in response to inflammation ${ }^{(18,19)}$. High circulating levels of $\boldsymbol{\gamma}$-tocopherol, that is, $>2.5 \mu \mathrm{g} / \mathrm{ml}$, do not appear to reflect dietary intake, rather they represent a response to

Abbreviations: BEAN Study, Breast, Estrogen, and Nutrition Study; CRP, C-reactive protein; WCRF/AICR, World Cancer Research Fund and American Institute for Cancer Research. 
the presence of an inflammatory stimulus. Individuals with circulating levels of $\gamma$-tocopherol $>2.5 \mu \mathrm{g} / \mathrm{ml}$ are considered hyper $\gamma$-tocopherolaemic ${ }^{(20)}$; such elevated levels are associated with low vitamin D status ${ }^{(20,21)}$, obesity ${ }^{(22)}$, age ${ }^{(23)}$, smoking ${ }^{(20)}$ and $\mathrm{CRP}^{(22)}$. Thus, $\gamma$-tocopherol may be an excellent overall marker of health risk. We hypothesised that women with high adherence to the WCRF/AICR recommendations have a more favourable inflammatory biomarker profile. In addition, we explored the association between BMI and the same biomarkers of antioxidant and inflammatory status.

(a)
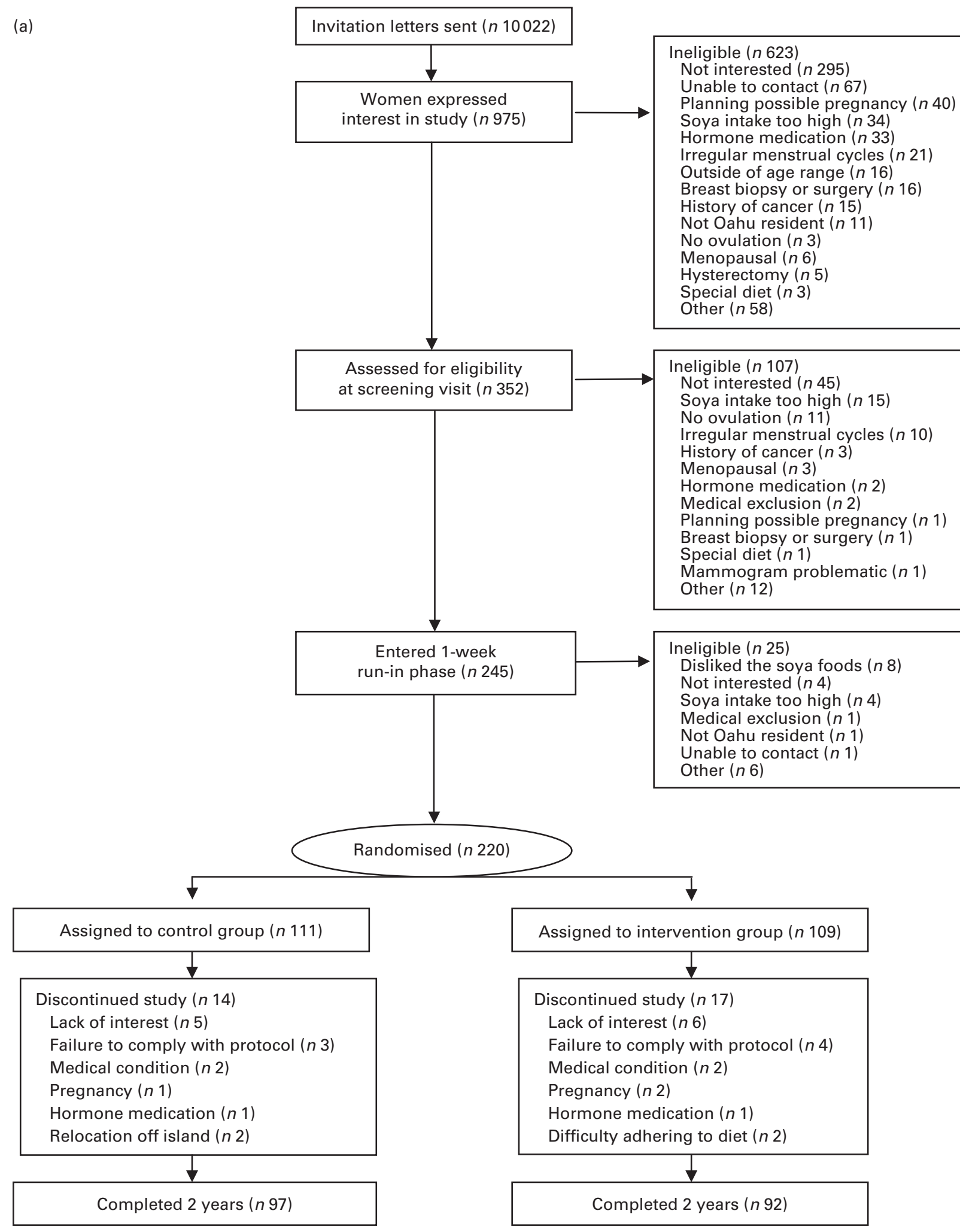


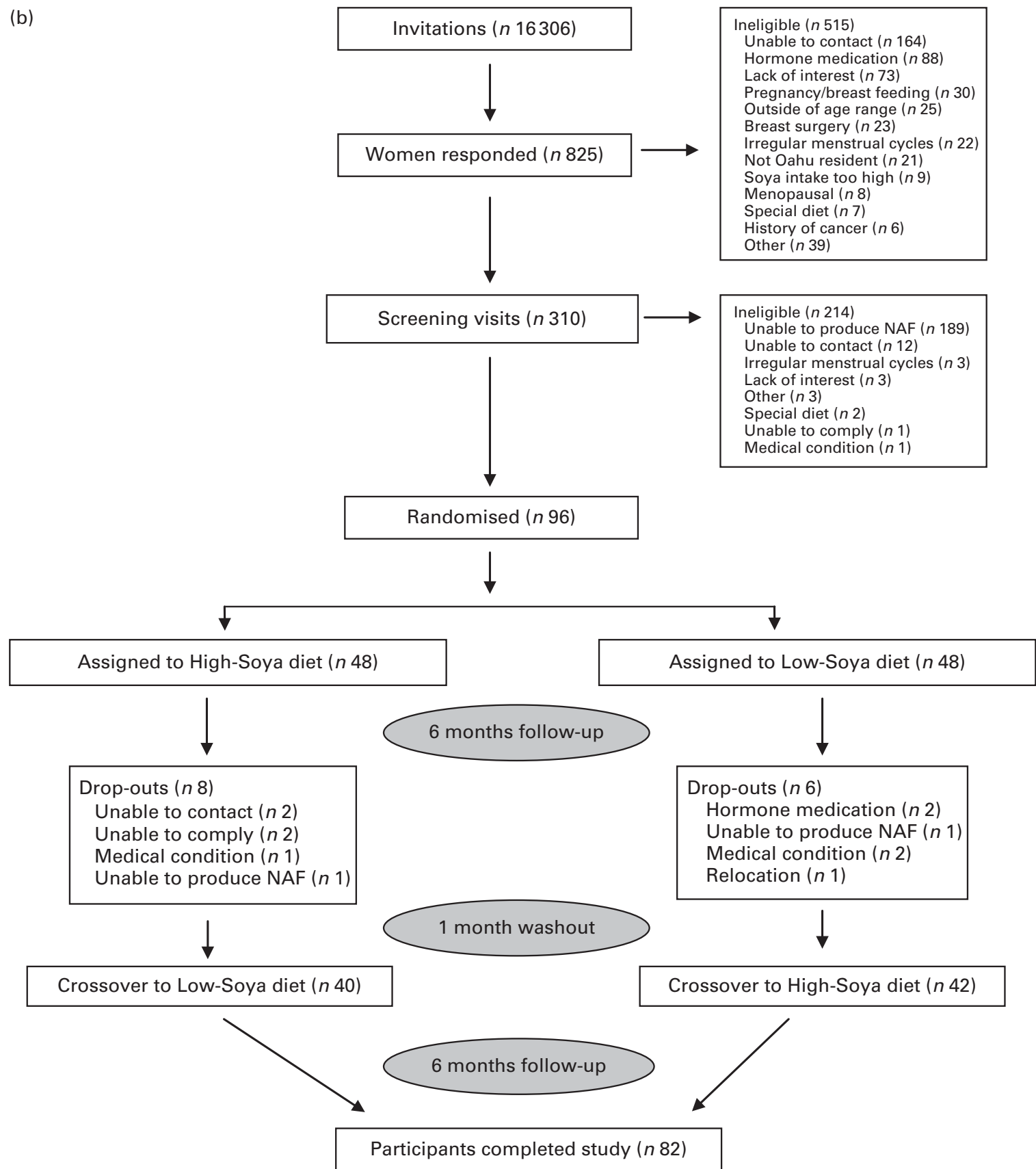

Fig. 1. Flow chart for recruitment and study population of the Breast, Estrogen, and Nutrition 1 (BEAN1) Study (a) and the Breast, Estrogen, and Nutrition 2 (BEAN2) Study (b). NAF, nipple aspirate fluid.

\section{Methods}

\section{Study design and population}

The current analysis used baseline data from two dietary intervention studies (Fig. 1): the Breast, Estrogen, and Nutrition (BEAN1), which randomised 220 women to a 2-year clinical trial to examine the effects of two daily soya servings on sex steroids and mammographic densities ${ }^{(24)}$, and BEAN2, which was conducted in a cross-over design with eighty-two women ${ }^{(25)}$. Only data collected at baseline before randomisation to an intervention were analysed. The protocols for both studies were approved by the University of Hawaii Committee on Human Studies and by the Institutional Review Boards of the participating hospitals. All participants signed an informed consent form before entry into the trials. As described in detail previously ${ }^{(24,25)}$, eligibility criteria for both studies included a normal mammogram, no breast implants, no current oral contraceptive use or pregnancy, no previous cancer diagnosis, intact uterus and ovaries, regular menstrual cycles, and low soya intake. Additional criteria for BEAN2 included the ability to produce at least $10 \mu \mathrm{l}$ nipple aspirate fluid, one of the study outcomes ${ }^{(25)}$. After exclusion 
Table 1. Scoring for World Cancer Research Fund and American Institute for Cancer Research (WCRF/AICR) recommendations based on data from baseline FFQ (Number of women and percentages)

\begin{tabular}{|c|c|c|c|c|c|}
\hline \multirow[b]{2}{*}{ WCRF/AICR recommendation } & \multirow[b]{2}{*}{ Associated recommendations used in this study } & \multirow[b]{2}{*}{ Met/did not meet recommendation if: } & \multirow[b]{2}{*}{ Score } & \multicolumn{2}{|c|}{ Women $(n$ 275) } \\
\hline & & & & $n$ & $\%$ \\
\hline \multirow{2}{*}{$\begin{array}{l}\text { Body fatness: be as lean as possible without } \\
\text { becoming underweight }\end{array}$} & \multirow[t]{2}{*}{ Maintain body weight in the normal BMI range } & Met: BMI between 18.5 and $25 \mathrm{~kg} / \mathrm{m}^{2}$ & 1 & 138 & $50 \cdot 2$ \\
\hline & & Did not meet: BMI $<18.5$ or $\geq 25 \mathrm{~kg} / \mathrm{m}^{2}$ & 0 & 137 & $49 \cdot 8$ \\
\hline \multirow{2}{*}{$\begin{array}{l}\text { Physical activity: be physically active for } \\
\text { at least } 30 \text { min every day }\end{array}$} & \multirow{2}{*}{$\begin{array}{l}\text { Be moderately or strenuously } \\
\text { physically active at least } 3.5 \mathrm{~h} / \text { week }\end{array}$} & Met: $\geq 3.5 \mathrm{~h} /$ week & 1 & 178 & $64 \cdot 7$ \\
\hline & & Did not meet: $<3.5 \mathrm{~h} /$ week & 0 & 97 & $35 \cdot 3$ \\
\hline \multirow{2}{*}{$\begin{array}{l}\text { Energy density: limit consumption of } \\
\text { energy dense foods: avoid sugary drinks }\end{array}$} & \multirow[t]{2}{*}{ Limit the consumption of sugary drinks to $<250 \mathrm{~g} / \mathrm{d}$} & Met: $<250 \mathrm{~g} / \mathrm{d}$ & 1 & 196 & $71 \cdot 3$ \\
\hline & & Did not meet: $\geq 250 \mathrm{~g} / \mathrm{d}$ & 0 & 79 & $28 \cdot 7$ \\
\hline \multirow{3}{*}{$\begin{array}{l}\text { Plant foods: eat more of a variety of } \\
\text { vegetables, fruits, whole } \\
\text { grains and legumes such as beans }\end{array}$} & \multirow[t]{3}{*}{$\begin{array}{l}\text { Eat } 5 \text { servings of fruits and vegetables and } \\
1 \text { serving or more of whole grains }\end{array}$} & $\begin{array}{l}\text { Met: } \geq 5 \text { servings } / d \\
\geq 1 \text { serving } / \mathrm{d}\end{array}$ & 1 & 87 & $31 \cdot 6$ \\
\hline & & $\begin{array}{l}\text { Did not meet: } \geq 5 \text { servings } / d \\
<1 \text { serving } / d\end{array}$ & 0 & 18 & $6 \cdot 5$ \\
\hline & & Did not meet: $<5$ servings $/ \mathrm{d}$ & 0 & 170 & 61.9 \\
\hline \multirow{2}{*}{$\begin{array}{l}\text { Red meat: limit consumption of red meats } \\
\text { (such as beef, pork and lamb) } \\
\text { and avoid processed meats }\end{array}$} & \multirow{2}{*}{$\begin{array}{l}\text { Limit red/processed meat consumption to } \\
<2.5 \text { servings/d ( } 2.5 \text { servings based on } 500 \mathrm{~g} / \text { week) }\end{array}$} & Met: $<2.5$ servings $/ d$ & 1 & 243 & 88.4 \\
\hline & & Did not meet: $\geq 2.5$ servings $/ \mathrm{d}$ & 0 & 32 & $11 \cdot 6$ \\
\hline \multirow[t]{2}{*}{ Alcohol: limit alcoholic drinks } & \multirow{2}{*}{$\begin{array}{l}\text { If alcoholic drinks are consumed, limit consumption } \\
\text { to no more than } 1 \text { drink/d }\end{array}$} & Met: $\leq 1 \mathrm{drink} / \mathrm{d}$ & 1 & 248 & $90 \cdot 2$ \\
\hline & & Did not meet: $<1$ drink $/ \mathrm{d}$ & 0 & 27 & $9 \cdot 8$ \\
\hline \multirow{2}{*}{$\begin{array}{l}\text { Salty foods: limit consumption of salt; } \\
\text { avoid moldy grains or legumes }\end{array}$} & \multirow{2}{*}{$\begin{array}{l}\text { Limit consumption of salty and processed } \\
\text { foods to }<2400 \mathrm{mg} / \mathrm{d}\end{array}$} & Met: $<2400 \mathrm{mg} / \mathrm{d}$ & 1 & 132 & $48 \cdot 0$ \\
\hline & & Did not meet: $\geq 2400 \mathrm{mg} / \mathrm{d}$ & 0 & 143 & $52 \cdot 0$ \\
\hline \multirow{3}{*}{$\begin{array}{l}\text { Smoking: do not smoke and avoid } \\
\text { tobacco smoke }\end{array}$} & \multirow{3}{*}{$\begin{array}{l}\text { Do not smoke or quit smoking if you are } \\
\text { a present smoker }\end{array}$} & Met: Never & 1 & 179 & $65 \cdot 1$ \\
\hline & & Met: Past & 1 & 17 & $6 \cdot 2$ \\
\hline & & Did not meet: current & 0 & 79 & 28.7 \\
\hline $\begin{array}{l}\text { Supplements: aim to meet nutritional } \\
\text { needs through diet alone }\end{array}$ & $\begin{array}{l}\text { Dietary supplements are not recommended } \\
\text { for cancer prevention }\end{array}$ & Not operationalised & $\mathrm{N} / \mathrm{A}$ & & \\
\hline
\end{tabular}

$\mathrm{N} / \mathrm{A}$, not available. 
of dropouts and women with incomplete data, the current analysis included 275 women who provided biological samples and complete nutritional information from the baseline FFQ that could be used to score adherence to the WICR/AICR recommendations (Table 1)

\section{Data collection}

All participants completed a previously validated FFQ at baseline that included questions on habitual dietary intake during the last year, physical activity, smoking status, medical history and reproductive characteristics ${ }^{(26)}$. The FFQ had eight frequency categories for foods and nine for beverages. Respondents could choose from three typical serving sizes and photographs were included to help visualise proportions for selected foods. BMI was calculated from baseline weight and height. The FFQ were analysed utilising the Food Composition Table maintained by the Nutrition Support Shared Resource at the Cancer Center ${ }^{(27)}$; the databases represent an extensive list of local foods consumed by the various ethnic populations of Hawaii and the Pacific. Food servings were defined according to the Food Guide Pyramid ${ }^{(28)}$.

\section{Sample collection and assays}

Serum and urine samples were collected during the midluteal phase using ovulation kits in BEAN1 and confirmation by serum progesterone levels ${ }^{(24)}$ and self-reported menstruation information in BEAN2 ${ }^{(25)}$. For this analysis, CRP and serum $\boldsymbol{\gamma}$-tocopherol were available for BEAN1 participants only and urinary F2-isoprostane levels for BEAN2 women only. All specimens were stored at $-80^{\circ} \mathrm{C}$ after aliquoting. The CRP assay was based on a latex particle enhanced immunoturbidimetric method using a Cobas MiraPlus clinical autoanalyser and a kit from Pointe Scientific, Inc., with a detection limit of $0 \cdot 1 \mathrm{mg} / \mathrm{l}^{(29)}$. Serum samples were analysed for $\gamma$-tocopherol by reverse phase HPLC with photodiode array detection between 220 and $600 \mathrm{~nm}^{(30,31)}$. The assay was regularly validated during the analysis by inclusion of external standards within each sample batch and through successful participation in the quality assurance program organised by US National Institute of Standards and Technology. Levels of urinary $15-\mathrm{F}_{2 \mathrm{t}}$-isoprostane were measured using an enzyme-linked immunosorbent assay kit (Oxford Biomedical Research) in six batches ${ }^{(32)}$.

\section{Statistical analysis}

All statistical analyses were performed using SAS, release 9.4 (SAS Institute, Inc.). A scoring system for eight of the ten recommendations by the WCRF/AICR for cancer prevention ${ }^{(1)}$ was modeled similar to a previous publication ${ }^{(3)}$. Participants were given a score of 1 or 0 depending on if they met or did not meet a recommendation (Table 1 ), and the adherence scores were classified as low $(<5)$, moderate $(5-6)$, and high $(\geq 7)$. Analyses for BMI status were based on pre-determined BMI categories: normal $\left(<25 \mathrm{~kg} / \mathrm{m}^{2}\right)$, overweight $\left(25-<30 \mathrm{~kg} / \mathrm{m}^{2}\right)$ and obese $\left(\geq 30 \mathrm{~kg} / \mathrm{m}^{2}\right)$. Because only
Table 2. Baseline characteristics of 275 premenopausal women from two intervention studies*

(Number of premenopausal women and percentages; mean values and standard deviations)

\begin{tabular}{|c|c|c|c|}
\hline \multirow[b]{2}{*}{ Characteristic } & \multicolumn{3}{|c|}{ BEAN1 and BEAN2 } \\
\hline & $n$ & & $\%$ \\
\hline \multicolumn{4}{|l|}{ Ethnicity } \\
\hline White & 112 & & $40 \cdot 7$ \\
\hline Asian & 99 & & $36 \cdot 0$ \\
\hline Native Hawaiian & 38 & & $13 \cdot 8$ \\
\hline Other & 26 & & 9.5 \\
\hline Age (years) & 41.9 & & 4.5 \\
\hline BMI $\left(\mathrm{kg} / \mathrm{m}^{2}\right)$ & $26 \cdot 1$ & & $5 \cdot 7$ \\
\hline \multicolumn{4}{|l|}{ Parity } \\
\hline No & 204 & & 74.2 \\
\hline Yes & 71 & & $25 \cdot 8$ \\
\hline \multicolumn{4}{|c|}{ Biospecimen collection in luteal phase } \\
\hline No & 37 & & 13.5 \\
\hline Yes & 238 & & 86.5 \\
\hline \multicolumn{4}{|l|}{ Smoking status } \\
\hline Never & 179 & & $65 \cdot 1$ \\
\hline Past & 17 & & $6 \cdot 2$ \\
\hline Current & 79 & & 28.7 \\
\hline Serum C-reactive protein $(\mathrm{mg} / \mathrm{l}) \dagger$ & $2 \cdot 1$ & & $3 \cdot 2$ \\
\hline Serum $\gamma$-tocopherol $(\mu \mathrm{g} / \mathrm{ml}) \dagger$ & 1.69 & & 0.96 \\
\hline Urinary F2-isoprostane $(\mathrm{ng} / \mathrm{ml}) \dagger$ & $14 \cdot 6$ & & $5 \cdot 3$ \\
\hline \multicolumn{4}{|l|}{ Dietary intake from baseline FFQ } \\
\hline \multicolumn{4}{|l|}{ Total energy $(\mathrm{kcal} / \mathrm{d})$} \\
\hline Mean & \multicolumn{3}{|c|}{1911} \\
\hline SD & \multicolumn{3}{|c|}{893} \\
\hline \multicolumn{4}{|l|}{ Red/processed meat (servings/d) } \\
\hline Mean & \multirow{2}{*}{\multicolumn{3}{|c|}{$1 \cdot 3$}} \\
\hline SD & \multicolumn{2}{|r|}{$1 \cdot 1$} & \\
\hline \multicolumn{4}{|l|}{ Whole grain (servings/d) } \\
\hline Mean & \multicolumn{3}{|c|}{1.9} \\
\hline SD & \multicolumn{3}{|c|}{1.5} \\
\hline \multicolumn{4}{|l|}{ Dietary fibre $(\mathrm{g} / \mathrm{d})$} \\
\hline Mean & \multicolumn{3}{|c|}{$20 \cdot 1$} \\
\hline SD & & 11.6 & \\
\hline Total energy from fat (\%) & & & \\
\hline Mean & & $32 \cdot 6$ & \\
\hline SD & & $6 \cdot 0$ & \\
\hline Fruit (servings/d) & & & \\
\hline Mean & & 1.5 & \\
\hline SD & & 1.6 & \\
\hline Vegetables (servings/d) & & & \\
\hline Mean & & $3 \cdot 3$ & \\
\hline SD & & $2 \cdot 4$ & \\
\hline Fruit and vegetables (servings/ & & & \\
\hline Mean & & $4 \cdot 8$ & \\
\hline SD & & 3.4 & \\
\hline Alcohol (drinks/d) & & & \\
\hline Mean & & 0.3 & \\
\hline SD & & 0.6 & \\
\hline Regular soda (g/d) & & & \\
\hline Mean & & 50 & \\
\hline SD & & 140 & \\
\hline $\mathrm{Na}(\mathrm{mg} / \mathrm{d})$ & & & \\
\hline Mean & & 2781 & \\
\hline SD & & 1469 & \\
\hline Physical activity (h/week) & & & \\
\hline Mean & & $7 \cdot 7$ & \\
\hline SD & & 8.0 & \\
\hline
\end{tabular}

BEAN, Breast, Estrogen, and Nutrition.

${ }^{*}$ Percentages may not add to 100 due to rounding.

†Serum $\gamma$-tocopherol and C-reactive protein (CRP) were available for BEAN1 only and urinary F2-isoprostane levels for BEAN2 only. Data were missing for serum $\gamma$-tocopherol $(n 23)$ and serum CRP $(n 12)$. 
three women had a BMI $<18.5 \mathrm{~kg} / \mathrm{m}^{2}$, these participants were excluded from the analyses. An indicator variable with a cut-off of $2.5 \mu \mathrm{g} / \mathrm{ml}$ for hyper $\gamma$-tocopherolaemic status was created. Means and standard deviations for dietary and lifestyle habits as well as biomarkers were computed by level of adherence and by BMI status. Non-normally distributed variables were log-transformed to obtain $P$-values for trend tests across categories using analysis of variance. In adjusted models, we included age, parity, ethnicity and timing of biospecimen collection within the luteal phase (yes or no) as covariates and expressed the differences as least square means with $95 \%$ CI. Finally, we examined the distribution of hyper $\gamma$-tocopherolaemia by adherence category and computed OR and $95 \% \mathrm{CI}$ in a logistic regression model with low adherers as the reference group.

\section{Results}

The study population (Table 2 ) consisted of $41 \%$ whites, $36 \%$ Asians, 14\% Native Hawaiians and 9\% Others with a mean age of 41.9 (SD 4.5 ) years. The mean BMI was 26.1 (SD $5.7) \mathrm{kg} / \mathrm{m}^{2}$ with $27 \%$ classified as overweight and $22 \%$ as obese. Of all biospecimens, $87 \%$ were collected during the luteal phase. The majority of participants (Table 1) were never smokers $(65 \%)$, met the physical activity guideline (65\%) and reported drinking one or fewer alcoholic beverages per day $(90 \%)$. As to nutritional recommendations, recommendations*

(Number of women and percentages; mean values and standard deviations)
$88 \%$ adhered to low red/processed meat intake, $71 \%$ to low soda intake, but only $48 \%$ limited salt intake to $<2400 \mathrm{mg} / \mathrm{d}$, and $32 \%$ consumed adequate amounts of vegetables, fruits and whole grains. The respective means for CRP, $\gamma$-tocopherol and F2-isoprostances were $2 \cdot 1 \mathrm{mg} / 1,1.7 \mu \mathrm{g} / \mathrm{ml}$ and $14.6 \mathrm{ng} / \mathrm{ml}$. Levels of serum $\gamma$-tocopherol and CRP were significantly correlated $0 \cdot 24(P=0 \cdot 001)$.

Overall, seventy-two women were classified as lowadherers, 150 as moderate adherers, and fifty-three as high-adherers (Table 3). The low adherers had a mean BMI of $30 \cdot 3(\mathrm{sD} 6 \cdot 0) \mathrm{kg} / \mathrm{m}^{2}$, while the mean BMI of the high adhering women was $22 \cdot 2(\mathrm{SD} 2 \cdot 0) \mathrm{kg} / \mathrm{m}^{2}$. High adherers were also more physically active $\left(P_{\text {trend }}<0 \cdot 0001\right)$, consumed less red/ processed meat $\left(P_{\text {trend }}<0.0001\right)$, lower percentage total energy from fat $\left(P_{\text {trend }}=0.002\right)$, less salt $\left(P_{\text {trend }}<0.0001\right)$ and more dietary fibre $\left(P_{\text {trend }}=0.01\right)$ and more fruits and vegetables $\left(P_{\text {trend }}=0.002\right)$. The unadjusted means for CRP (BEAN1 only) were $2 \cdot 7,2.0$ and $1.7 \mathrm{mg} / 1$ for low, moderate and high adherers $\left(P_{\text {trend }}=0.03\right)$; this association was strengthened after adjustment for potential confounders with least square means for log-transformed CRP values of $1 \cdot 12$, 0.87 and $0.71 \mathrm{mg} / 1\left(P_{\text {trend }}=0.006\right)$. The respective values for serum $\gamma$-tocopherol (BEAN1 only) were $1.97,1.63$ and $1.45 \mu \mathrm{g} / \mathrm{ml}\left(P_{\text {trend }}=0.02\right)$ before and $1 \cdot 10,0.96$, and $0.91 \mu \mathrm{g} / \mathrm{ml}$ $\left(P_{\text {trend }}=0.03\right)$ after adjustment. However, for urinary F2-isoprostane (BEAN2 only), the higher values in low adherers $(16 \cdot 0,14 \cdot 5$, and $13.3 \mathrm{ng} / \mathrm{ml})$ did not reach statistical significance

Table 3. Characteristics of women by adherence to World Cancer Research Fund and American Institute for Cancer Research

\begin{tabular}{|c|c|c|c|c|c|c|c|c|}
\hline & \multicolumn{2}{|c|}{$\begin{array}{c}\text { Low } \\
\text { adherence } \\
(\leq 4)\end{array}$} & \multicolumn{2}{|c|}{$\begin{array}{c}\text { Moderate } \\
\text { adherence } \\
(5-6)\end{array}$} & \multicolumn{2}{|c|}{$\begin{array}{c}\text { High } \\
\text { adherence } \\
(\geq 7)\end{array}$} & \multirow[b]{2}{*}{$P_{\text {unadjusted }} \dagger$} & \multirow[b]{2}{*}{$P_{\text {adjusted }} \dagger$} \\
\hline & $n$ & $\%$ & $n$ & $\%$ & $n$ & $\%$ & & \\
\hline$n$ & \multicolumn{2}{|c|}{72} & \multicolumn{2}{|c|}{150} & \multicolumn{2}{|c|}{53} & & \\
\hline Age (years) & & & & & & & $0 \cdot 15$ & \\
\hline Mean & \multicolumn{2}{|c|}{$42 \cdot 8$} & \multicolumn{2}{|c|}{41.6} & \multicolumn{2}{|c|}{$41 \cdot 8$} & & \\
\hline SD & \multicolumn{2}{|c|}{$3 \cdot 3$} & \multicolumn{2}{|c|}{4.7} & \multicolumn{2}{|c|}{$5 \cdot 0$} & & \\
\hline Ethnicity & & & & & & & $0 \cdot 16$ & \\
\hline White & 23 & 31.9 & 62 & $41 \cdot 3$ & 27 & $50 \cdot 9$ & & \\
\hline Asian & 29 & $40 \cdot 3$ & 51 & 34.0 & 19 & 35.9 & & \\
\hline Native Hawaiian & 12 & $16 \cdot 7$ & 24 & $16 \cdot 0$ & 2 & $3 \cdot 8$ & & \\
\hline Other & 8 & $11 \cdot 1$ & 13 & $8 \cdot 7$ & 5 & $9 \cdot 4$ & & \\
\hline Serum CRP (mg/l)‡ & & & \multirow{2}{*}{\multicolumn{2}{|c|}{$2 \cdot 0$}} & \multirow{2}{*}{\multicolumn{2}{|c|}{1.7}} & 0.03 & 0.006 \\
\hline Mean & \multicolumn{2}{|c|}{$2 \cdot 7$} & & & & & & \\
\hline SD & \multicolumn{2}{|c|}{3.5} & \multicolumn{2}{|c|}{$3 \cdot 2$} & \multicolumn{2}{|c|}{$2 \cdot 7$} & & \\
\hline Serum $\gamma$-tocopherol $(\mu \mathrm{g} / \mathrm{ml}) \ddagger$ & & & & & & & 0.02 & 0.03 \\
\hline Mean & \multicolumn{2}{|c|}{1.97} & \multicolumn{2}{|c|}{$1 \cdot 63$} & \multicolumn{2}{|c|}{1.45} & & \\
\hline SD & \multicolumn{2}{|c|}{1.01} & \multicolumn{2}{|c|}{0.94} & \multicolumn{2}{|c|}{0.83} & & \\
\hline Hyper $\gamma$-tocopherolaemia $(\geq 2.5 \mu \mathrm{g} / \mathrm{ml})$ & 12 & 25 & 15 & 17 & 4 & 12 & 0.29 & \\
\hline Urinary F2-isoprostane $(\mathrm{ng} / \mathrm{ml}) \ddagger$ & \multirow{2}{*}{\multicolumn{2}{|c|}{$16 \cdot 0$}} & & & & & 0.18 & 0.21 \\
\hline Mean & & & \multicolumn{2}{|c|}{14.5} & \multicolumn{2}{|c|}{$13 \cdot 3$} & & \\
\hline SD & \multicolumn{2}{|c|}{$7 \cdot 2$} & \multicolumn{2}{|c|}{$4 \cdot 8$} & \multicolumn{2}{|c|}{$3 \cdot 8$} & & \\
\hline
\end{tabular}

CRP, C-reactive protein.

* Percentages may not add to 100 due to rounding.

$\dagger P_{\text {trend }}$ values were computed for continuous variables using log-transformed data except for age and \% total energy from fat. $P$ values for categorical variables were computed using $\chi^{2}$ or Fisher's exact test. Adjusted model included age, parity, ethnicity, and timing of biospecimen collection within the luteal phase (yes or no) as covariates.

$\ddagger$ Serum $\gamma$-tocopherol and CRP were available for Breast, Estrogen, and Nutrition 1 (BEAN1) only and urinary F2-isoprostane levels for Breast, Estrogen, and Nutrition 2 (BEAN2) only. Data were missing for serum $\gamma$-tocopherol $(n 23)$ and serum CRP $(n 12)$. 
(a)

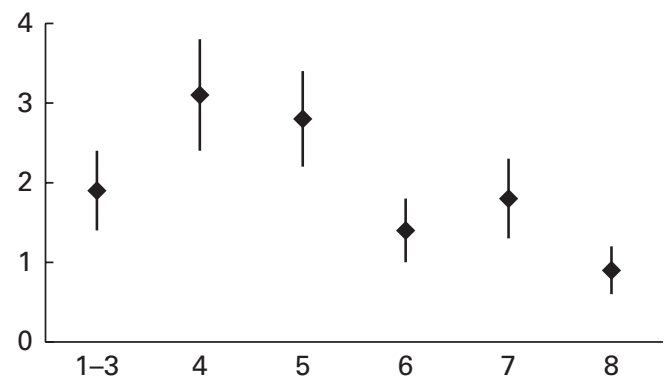

(b)

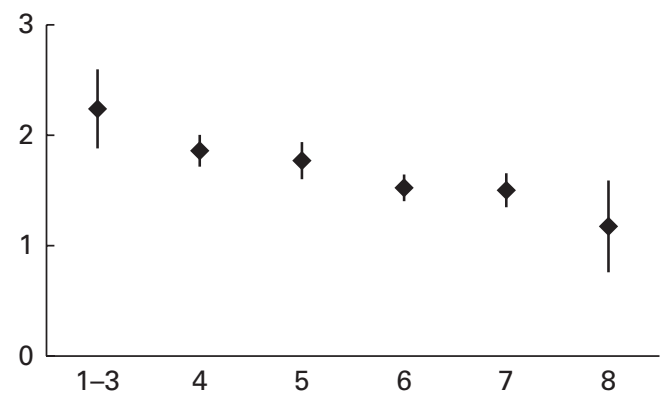

(c)

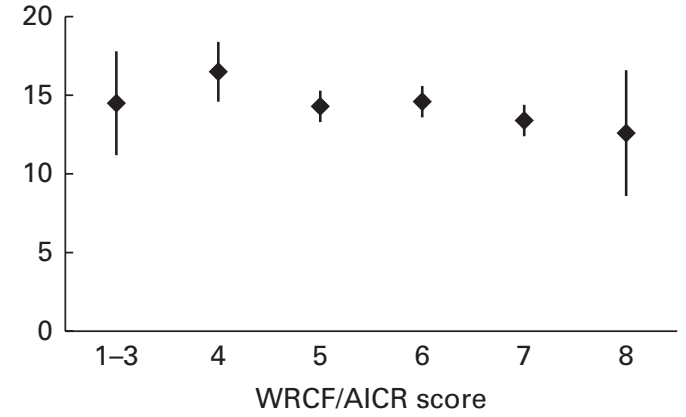

Fig. 2. Mean biomarker levels and standard errors by World Cancer Research Fund and American Institute for Cancer Research (WCRF/AICR) score. (a) Serum C-reactive protein $\left(\mathrm{mg} / \mathrm{l}, P_{\text {trend }}<0.01\right)$, (b) serum $\alpha$-tocopherol $\left(\mu \mathrm{g} / \mathrm{ml}, \quad P_{\text {trend }}<0.01\right)$ and (c) urinary F2-isoprostane $(\mathrm{ng} / \mathrm{l}$, $\left.P_{\text {trend }}=0.27\right)$. Missing data were recorded for (a) $(n 23)$ and (b) $(n 12) . P_{\text {trend }}$ values were computed using log-transformed biomarker levels.

$\left(P_{\text {trend }}=0 \cdot 18\right)$. In the adjusted models, the respective F2-isoprostane values were $2 \cdot 74,2.66$ and $2.60 \mathrm{ng} / \mathrm{ml}\left(P_{\text {trend }}=0 \cdot 21\right)$.

The inverse associations for the biomarkers with higher adherence (Fig. 2) were more pronounced for CRP $\left(P_{\text {trend }}<0.01\right)$ and $\gamma$-tocopherol $\left(P_{\text {trend }}<0.01\right)$ than for F2-isoprostane $\left(P_{\text {trend }}=0 \cdot 27\right)$. Whereas the mean levels by adherence score were more or less flat for F2-isoprostane, serum $\gamma$-tocopherol showed a continuous decline from $>2 \cdot 0$ to $<1.5 \mu \mathrm{g} / \mathrm{ml}$ across categories. We observed smaller proportions of women with hyper $\gamma$-tocopherolaemia among moderate and high adherers than in low adherers (17 and $12 v .25 \%$, respectively). However, the respective OR of 0.60 (95\% CI $0 \cdot 26,1 \cdot 41)$ and $0.41(95 \%$ CI $0 \cdot 12,1 \cdot 42)$ for moderate and high adherers $v$. low adherers were not statistically significant. For CRP, the levels were up to twice as high for the three lower categories than for women scoring 6 to 8 .

When participants were grouped by BMI category (Table 4), $\mathrm{red} /$ processed meat, percentage of total energy from fat and $\mathrm{Na}$ intake were significantly higher and physical activity significantly lower in overweight and obese than normal weight women. AICR scores not including BMI were lowest in the obese group, followed by overweight and normal weight women with respective values of 4.3 (SD 1.0), 4.8 (SD $1 \cdot 2)$ and $5 \cdot 1$ (SD 1.0). The levels of CRP, $\gamma$-tocopherol and F2-isoprostane were substantially higher in overweight and obese than normal weight women; these trends remained unchanged after adjustment for age, ethnicity, parity and luteal phase. However, the linear trend was only statistically significant for CRP and $\gamma$-tocopherol with log-transformed values of $0.56,0.96$ and $1.38\left(P_{\text {trend }}<0.0001\right)$ and $7.20,7.40$ and $7.55\left(P_{\text {trend }}=0.008\right)$, respectively. The respective least square means for F2-isoprostane were 2.64, 2.57 and 2.83 $\left(P_{\text {trend }}=0.21\right)$ across BMI categories.

\section{Discussion}

In the present study of multi-ethnic premenopausal women, many women met a high proportion of the eight recommendations operationalised according to the WCRF/AICR cancer prevention guidelines, in particular, limiting the consumption of energy-dense food such as sodas, red/processed meat and alcohol. Women with lower adherence scores had a higher BMI and reported higher intakes of unfavourable foods and behaviours. The results of this study suggest a weak inverse relation between adherence to nutritional and lifestyle recommendations and two of the three markers of antioxidant and inflammatory status examined. Specifically, $\gamma$-tocopherol and CRP, but not F2-isoprostane, were lower in women with higher adherence scores. In a similar pattern, overweight and obese women had substantially higher levels of all three biomarkers than normal weight women; in particular, CRP was nearly fivefold higher in obese women. In response to the inflammatory stress marked by low adherence scores and excess body weight, $\gamma$-tocopherol appears to rise as a physiological mechanism to protect the body against inflammation-related damage. Although a well-established marker of inflammation, urinary F2-isoprostane showed little association with adherence scores and BMI status.

To our knowledge, this is the first analysis to examine the association between WCRF/AICR recommendations and biomarkers of inflammation and antioxidant status. Previous studies investigated adherence to WCRF/AICR recommendations with morbidity and mortality in women. For example, a 22 to $24 \%$ lower cancer-specific mortality for meeting one to two recommendations and $61 \%$ lower for meeting five to six recommendations were reported ${ }^{(3)}$. A larger cohort observed similar results with a $34 \%$ lower mortality for individuals who met six to seven recommendations ${ }^{(2)}$. The association between excess body weight and elevated CRP levels is well known and has been described for many populations ${ }^{(33,34)}$.

The association of overweight with the biomarkers may be due to cytokines produced in adipose tissue or due to direct effects of dietary components associated with a high BMI. For example, obese women consumed more red/processed meat, fat and salt, food components that were related to higher $\gamma$-tocopherol in a previous report ${ }^{(35)}$. While dietary intake of $\gamma$-tocopherol and blood levels are poorly correlated ${ }^{(36-39)}$, $\mathrm{red} /$ processed meat consumption is thought to be related to 
Table 4. Characteristics of women by BMI category*

(Mean values and standard deviations; number of women and percentages)

\begin{tabular}{|c|c|c|c|c|c|c|c|c|}
\hline & \multicolumn{2}{|c|}{$\begin{array}{c}\text { Normal } \\
\left(18.5-<25.0 \mathrm{~kg} / \mathrm{m}^{2}\right)\end{array}$} & \multicolumn{2}{|c|}{$\begin{array}{c}\text { Overweight } \\
\left(25.0-29.9 \mathrm{~kg} / \mathrm{m}^{2}\right)\end{array}$} & \multicolumn{2}{|c|}{$\begin{array}{c}\text { Obese } \\
\left(>30 \mathrm{~kg} / \mathrm{m}^{2}\right)\end{array}$} & \multirow[b]{2}{*}{$P_{\text {unadjusted }} \dagger$} & \multirow[b]{2}{*}{$P_{\text {adjusted }} \uparrow$} \\
\hline & Mean & SD & Mean & SD & Mean & SD & & \\
\hline$n$ & \multicolumn{2}{|c|}{138} & \multicolumn{2}{|c|}{74} & \multicolumn{2}{|c|}{60} & & \\
\hline Age (years) & $41 \cdot 6$ & $4 \cdot 7$ & $42 \cdot 6$ & $3 \cdot 9$ & $41 \cdot 7$ & $4 \cdot 6$ & 0.62 & \\
\hline Smoking status & & & & & & & 0.13 & \\
\hline \multicolumn{9}{|l|}{ Never } \\
\hline$n$ & \multicolumn{2}{|c|}{96} & \multicolumn{2}{|c|}{48} & \multicolumn{2}{|c|}{35} & & \\
\hline$\%$ & \multicolumn{2}{|c|}{$68 \cdot 1$} & \multicolumn{2}{|c|}{$64 \cdot 8$} & \multicolumn{2}{|c|}{$58 \cdot 3$} & & \\
\hline \multicolumn{9}{|l|}{ Past } \\
\hline$n$ & \multicolumn{2}{|c|}{9} & \multicolumn{2}{|c|}{7} & \multicolumn{2}{|c|}{1} & & \\
\hline$\%$ & \multicolumn{2}{|c|}{6.4} & \multicolumn{2}{|c|}{95} & \multicolumn{2}{|c|}{$1 \cdot 7$} & & \\
\hline \multicolumn{9}{|l|}{ Current } \\
\hline$n$ & \multicolumn{2}{|c|}{36} & \multicolumn{2}{|c|}{19} & \multicolumn{2}{|c|}{24} & & \\
\hline$\%$ & \multicolumn{2}{|c|}{$25 \cdot 5$} & \multicolumn{2}{|c|}{$25 \cdot 7$} & \multicolumn{2}{|c|}{$40 \cdot 0$} & & \\
\hline Serum CRP (mg/l)‡ & $1 \cdot 0$ & $1 \cdot 1$ & $2 \cdot 3$ & $2 \cdot 8$ & $4 \cdot 7$ & 4.9 & $<0.001$ & $<0.0001$ \\
\hline Serum $\gamma$-tocopherol $(\mu \mathrm{g} / \mathrm{ml}) \ddagger$ & 1.49 & 0.91 & 1.79 & 1.04 & $2 \cdot 00$ & 0.88 & 0.003 & 0.008 \\
\hline Urinary F2-isoprostane (ng/ml)‡ & $14 \cdot 2$ & $4 \cdot 6$ & $13 \cdot 6$ & $5 \cdot 0$ & $17 \cdot 4$ & $6 \cdot 9$ & 0.14 & 0.21 \\
\hline Dietary intakes from baseline FFQ & & & & & & & & \\
\hline Total energy (kcal/d) & 1810 & 887 & 1944 & 798 & 2069 & 1001 & 0.10 & \\
\hline Red/processed meat (servings/d) & $1 \cdot 1$ & $1 \cdot 0$ & 1.4 & $1 \cdot 1$ & $1 \cdot 7$ & 1.0 & $<0.0001$ & \\
\hline Whole grains (servings/d) & $1 \cdot 6$ & $1 \cdot 8$ & $1 \cdot 8$ & 1.6 & $1 \cdot 8$ & $1 \cdot 6$ & 0.44 & \\
\hline Dietary fibre $(\mathrm{g} / \mathrm{d})$ & $20 \cdot 7$ & $12 \cdot 8$ & $19 \cdot 4$ & $9 \cdot 3$ & $19 \cdot 4$ & $11 \cdot 5$ & 0.49 & \\
\hline Total energy from fat (\%) & $31 \cdot 2$ & $6 \cdot 0$ & $34 \cdot 1$ & $5 \cdot 1$ & $34 \cdot 1$ & $6 \cdot 3$ & 0.0003 & \\
\hline Fruit (servings/d) & 1.6 & $1 \cdot 8$ & 1.6 & 1.4 & $1 \cdot 3$ & $1 \cdot 2$ & 0.18 & \\
\hline Vegetables (servings/d) & 3.4 & $2 \cdot 7$ & 3.4 & $2 \cdot 2$ & 2.9 & $1 \cdot 7$ & 0.31 & \\
\hline Fruit and vegetables (servings/d) & $5 \cdot 0$ & $4 \cdot 0$ & $4 \cdot 9$ & $3 \cdot 0$ & $4 \cdot 2$ & $2 \cdot 6$ & 0.18 & \\
\hline Alcohol (drinks/d) & 0.4 & 0.6 & 0.4 & 0.8 & $0 \cdot 2$ & 0.4 & 0.17 & \\
\hline Regular soda (g/d) & 58 & 179 & 30 & 68 & 61 & 99 & 0.18 & \\
\hline $\mathrm{Na}(\mathrm{mg} / \mathrm{d})$ & 2679 & 1557 & 2672 & 1294 & 3162 & 1457 & 0.01 & \\
\hline Physical activity (h/week) & $8 \cdot 9$ & $8 \cdot 7$ & $7 \cdot 1$ & $6 \cdot 8$ & $5 \cdot 7$ & $7 \cdot 1$ & 0.001 & \\
\hline WCRF/AICR score without BMI§ & $5 \cdot 1$ & $1 \cdot 0$ & $4 \cdot 8$ & $1 \cdot 2$ & $4 \cdot 3$ & $1 \cdot 0$ & $<0.0001$ & \\
\hline
\end{tabular}

CRP, C-reactive protein; WCRF/AICR, World Cancer Research Fund and American Institute for Cancer Research.

${ }^{*}$ Percentages may not add to 100 due to rounding. Three women with a BMI $<18.5 \mathrm{~kg} / \mathrm{m}^{2}$ were not included in the analysis.

$\dagger P_{\text {trend }}$ values were computed for continuous variables using log-transformed data except for age and \% total energy from fat. $P$ values for categorical variables were computed using $\chi^{2}$ or Fisher's exact test. Adjusted model included age, parity, ethnicity, and timing of biospecimen collection within the luteal phase (yes or no) as covariates.

‡Serum $\gamma$-tocopherol and CRP levels are available for Breast, Estrogen, and Nutrition 1 (BEAN1) only and urinary F2-isoprostane levels are available for Breast, Estrogen, and Nutrition 2 (BEAN2) only. Missing data were recorded for serum $\gamma$-tocopherol $(n 23)$ and serum CRP $(n 12)$.

$\S \mathrm{BMI}$ individual score was removed from the AICR score.

inflammatory responses during digestion, which may lead to an increase in circulating $\gamma$-tocopherols ${ }^{(40)}$. The stimulation of inflammatory cytokines by excess adiposity may also influence $\gamma$-tocopherol levels ${ }^{(20,41)}$. Among antioxidants, $\gamma$-tocopherol appears to be unique, in that higher circulating levels are directly associated with oxidative stress, whereas most antioxidants are reduced under conditions of oxidative stress ${ }^{(18,19)}$. The wide range of adverse conditions associated with elevated $\gamma$-tocopherol, and the general correlation with risk factors in the present study indicate it may be a useful integrative marker for assessing future disease risk. The occurrence of hyper $\gamma$-tocopherolaemia was weakly related to lower overall adherence scores without reaching statistical significance, suggesting a higher cutoff for defining this state might be indicated. Since very few supplements contain $\boldsymbol{\gamma}$-tocopherol, it is unlikely that high circulating $\boldsymbol{\gamma}$-tocopherol levels are due to supplement intake. While $\gamma$-tocopherol accounts for $80 \%$ of tocopherols in the diet, most is excreted or metabolised in healthy people $^{(36,39)}$

Strengths of the present study include the ethnic diversity of the women, as well as the use of a previously validated
$\mathrm{FFQ}^{(26)}$. We analysed baseline nutritional data prior to implementation of the study interventions, thereby capturing usual dietary and lifestyle habits from the year before dietary changes were initiated. Given the generally good health status of the participants, it is unlikely that unknown, underlying conditions affected the biomarker levels. By contrast, given the healthy status of the women, their high adherence to lifestyle recommendations, and the strict eligibility criteria, the participants probably represented a relatively narrow range in biomarker levels. Therefore, the results may not be generalisable to a population with a higher prevalence of chronic conditions. The study was also limited by the small sample size and the low statistical power, the lack of a general energy-density variable, and the absence of information on dietary supplement intake.

Diet-disease associations are difficult to determine due to the length of time required for quantifiable symptoms to be expressed and chronic diseases to develop. Elevated levels of biomarkers in healthy people may help to identify persons at a higher risk for chronic disease development later in life. The fact that WCRF/AICR adherence scores and BMI status 
showed similar associations with the three biomarkers suggests that the type of foods consumed may be less important in determining future disease risk than the excess body weight resulting from poor dietary patterns. The current findings suggest that adherence to the WCRF/AICR guidelines is associated with lower levels of biomarkers that indicate oxidative stress and inflammatory status, in particular, serum CRP and $\gamma$-tocopherol, and may lower future disease risk.

\section{Acknowledgements}

We are very grateful to the dedicated study participants.

This work was supported by grants R01CA80843 (principal investigator: G. M.) and P30CA71789 (principal investigator: M. Carbone) from the National Cancer Institute. The funding agency had no role in the design, analysis or writing of this article.

None of the authors has conflict of interest.

The authors' contributions are as follows: G. M. conceived the original studies, obtained funding, supervised the data analysis and finalised the manuscript. R. V. C. and A. A. F. provided laboratory results and interpreted the results. Y. M. and F. B. collated the statistical information and drafted the manuscript. All authors read and approved the findings of the study.

\section{References}

1. World Cancer Research Fund (2007) WCRF/AICR Expert Report, Food, Nutrition, Physical Activity and the Prevention of Cancer: A Global Perspective. Washington, DC: AICR.

2. Vergnaud AC, Romaguera D, Peeters PH, et al. (2013) Adherence to the World Cancer Research Fund/American Institute for Cancer Research guidelines and risk of death in Europe: results from the European Prospective Investigation into Nutrition and Cancer cohort study. Am J Clin Nutr 97, 1107-1120.

3. Hastert TA, Beresford SA, Sheppard L, et al. (2014) Adherence to the WCRF/AICR cancer prevention recommendations and cancer-specific mortality: results from the Vitamins and Lifestyle (VITAL) Study. Cancer Causes Control 25, 541-552.

4. Chaturvedi AK, Moore SC \& Hildesheim A (2013) Invited Commentary: circulating inflammation markers and cancer risk - implications for epidemiologic studies. Am J Epidemiol 177, 14-19.

5. Hanahan D \& Weinberg RA (2011) Hallmarks of cancer: the next generation. Cell 144, 646-674.

6. Albers R, Antoine JM, Bourdet-Sicard R, et al. (2005) Markers to measure immunomodulation in human nutrition intervention studies. Br J Nutr 94, 452-481.

7. Ollberding NJ, Kim Y, Shvetsov YB, et al. (2013) Prediagnostic leptin, adiponectin, C-reactive protein, and the risk of postmenopausal breast cancer. Cancer Prev Res (Phila) 6, $188-195$.

8. Cooney RV, Chai W, Franke AA, et al. (2013) C-reactive protein, lipid-soluble micronutrients, and survival in colorectal cancer patients. Cancer Epidemiol Biomarkers Prev 22, 1278-1288.

9. Magalhaes LM, Segundo MA, Reis S, et al. (2008) Methodological aspects about in vitro evaluation of antioxidant properties. Anal Chim Acta 613, 1-19.
10. Tsimikas S (2006) Measures of oxidative stress. Clin Lab Med 26, 571-590, v-vi.

11. Cracowski JL, Durand T \& Bessard G (2002) Isoprostanes as a biomarker of lipid peroxidation in humans: physiology, pharmacology and clinical implications. Trends Pharmacol Sci 23, 360-366.

12. Ju J, Picinich SC, Yang Z, et al. (2010) Cancer-preventive activities of tocopherols and tocotrienols. Carcinogenesis 31, 533-542.

13. Constantinou C, Papas A \& Constantinou AI (2008) Vitamin E and cancer: an insight into the anticancer activities of vitamin $\mathrm{E}$ isomers and analogs. Int J Cancer 123, 739-752.

14. Cooney RV, Franke AA, Harwood PJ, et al. (1993) $\gamma$-Tocopherol detoxification of nitrogen dioxide: superiority to $\alpha$-tocopherol. Proc Natl Acad Sci U S A 90, 1771-1775.

15. Christen S, Woodall AA, Shigenaga MK, et al. (1997) $\gamma$-Tocopherol traps mutagenic electrophiles such as $\mathrm{NO}(\mathrm{X})$ and complements $\alpha$-tocopherol: physiological implications. Proc Natl Acad Sci U S A 94, 3217-3222.

16. Tanaka Y \& Cooney RV (2007) Chemical and biologic properties of tocopherols and their relation to cancer incidence and progression. In The Encyclopedia of Vitamin E, pp. 853-863 [V Preedy and R Watson, editors]. New York: CABI Publishing.

17. Jiang Q \& Ames BN (2003) $\gamma$-Tocopherol, but not $\alpha$-tocopherol, decreases proinflammatory eicosanoids and inflammation damage in rats. FASEB J 17, 816-822.

18. Jiang Q, Lykkesfeldt J, Shigenaga MK, et al. (2002) $\gamma$-Tocopherol supplementation inhibits protein nitration and ascorbate oxidation in rats with inflammation. Free Radic Biol Med 33, 1534-1542.

19. Tanaka Y, Wood LA \& Cooney RV (2007) Enhancement of intracellular $\gamma$-tocopherol levels in cytokine-stimulated C3H 10T1/2 fibroblasts: relation to NO synthesis, isoprostane formation, and tocopherol oxidation. BMC Chem Biol 7, 2.

20. Cooney RV, Franke AA, Wilkens LR, et al. (2008) Elevated plasma $\gamma$-tocopherol and decreased $\alpha$-tocopherol in men are associated with inflammatory markers and decreased plasma 25-OH vitamin D. Nutr Cancer 60, Suppl. 1, 21-29.

21. Chai W, Bostick RM, Ahearn TU, et al. (2012) Effects of vitamin $\mathrm{D}_{3}$ and calcium supplementation on serum levels of tocopherols, retinol, and specific vitamin D metabolites. Nutr Cancer 64, 57-64.

22. Chai W, Maskarinec G \& Cooney RV (2010) Serum 25-hydroxyvitamin D levels and mammographic density among premenopausal women in a multiethnic population. Eur J Clin Nutr 64, 652-654.

23. Chai W, Novotny R, Maskarinec G, et al. (2014) Serum coenzyme $\mathrm{Q}_{10}, \alpha$-tocopherol, $\gamma$-tocopherol, and C-reactive protein levels and body mass index in adolescent and premenopausal females. J Am Coll Nutr 33, 192-197.

24. Maskarinec G, Franke AA, Williams AE, et al. (2004) Effects of a 2-year randomized soy intervention on sex hormone levels in premenopausal women. Cancer Epidemiol Biomarkers Prev 13, 1736-1744.

25. Maskarinec G, Morimoto Y, Conroy SM, et al. (2011) The volume of nipple aspirate fluid is not affected by 6 months of treatment with soy foods in premenopausal women. J Nutr 141, 626-630.

26. Stram DO, Hankin JH, Wilkens LR, et al. (2000) Calibration of the dietary questionnaire for a multiethnic cohort in Hawaii and Los Angeles. Am J Epidemiol 151, 358-370.

27. Murphy SP (2002) Unique nutrition support for research at the Cancer Research Center of Hawaii. Hawaii Med J 15, 17. 
28. Sharma S, Murphy SP, Wilkens LR, et al. (2003) Extending a multiethnic food composition table to include standardized food group servings. J Food Compos Anal 16, 485-495.

29. Maskarinec G, Steude JS, Franke AA, et al. (2009) Inflammatory markers in a 2-year soy intervention among premenopausal women. J Inflamm (Lond) 6, 9.

30. Franke AA, Custer LJ \& Cooney RV (1993) Synthetic carotenoids as internal standards for plasma micronutrient analysis by HPLC. J Chromatogr 614, 43-57.

31. Franke AA, Cooney RV, Henning SM, et al. (2005) Bioavailability and antioxidant effects of orange juice components in humans. J Agric Food Chem 53, 5170-5178.

32. Sen C, Morimoto Y, Heak S, et al. (2012) Soy foods and urinary isoprostanes: results from a randomized study in premenopausal women. Food Funct 3, 517-521.

33. Das UN (2001) Is obesity an inflammatory condition? Nutrition 17, 953-966.

34. Fogarty AW, Glancy C, Jones S, et al. (2008) A prospective study of weight change and systemic inflammation over 9 y. Am J Clin Nutr 87, 30-35.

35. Fung TT, Rimm EB, Spiegelman D, et al. (2001) Association between dietary patterns and plasma biomarkers of obesity and cardiovascular disease risk. Am J Clin Nutr $\mathbf{7 3}$, 61-67.

36. Institute of Medicine \& Food and Nutrition Board (2000) Dietary Reference Intakes for Vitamin C, Vitamin E, Selenium, and Carotenoids. Washington, DC: National Academies Press.

37. Office of Dietary Supplements of the National Institute of Health (2011) Dietary Supplement Fact Sheet: Vitamin E. Bethesda, MD: National Institutes of Health. http://ods.od. nih.gov/factsheets/VitaminE-HealthProfessional/

38. Dietrich M, Traber MG, Jacques PF, et al. (2006) Does $\gamma$-tocopherol play a role in the primary prevention of heart disease and cancer? A review. J Am Coll Nutr 25, 292-299.

39. Herrera E \& Barbas C (2001) Vitamin E: action, metabolism and perspectives. J Physiol Biochem 57, 43-56.

40. Montonen J, Boeing H, Fritsche A, et al. (2013) Consumption of red meat and whole-grain bread in relation to biomarkers of obesity, inflammation, glucose metabolism and oxidative stress. Eur J Nutr 52, 337-345.

41. Allin KH \& Nordestgaard BG (2011) Elevated C-reactive protein in the diagnosis, prognosis, and cause of cancer. Crit Rev Clin Lab Sci 48, 155-170. 